\title{
PENGEMBANGAN PROFIL SEKOLAH BERBASIS WEBSITE MENGGUNAKAN METODE OBJECT ORIENTED ANALYSIS AND DESIGN
}

\author{
Nyimas Sopiah ${ }^{1}$, Wawan Didit $\mathbf{M}^{2}$ \\ Universitas Bina Darma ${ }^{1,2}$ \\ Jalan Jenderal Ahmad Yani No.3 Palembang \\ Sur-el: nyimas.sopiah@binadarma.ac.id
}

\begin{abstract}
The school profile is one of the most important things in promoting a school. By displaying a school profile, visitors from a school can see all teaching and learning activities in a school. This is very important considering the school profile is also a promotional medium that can be displayed to others. In developing this school profile, the author is interested in making it use a website using analysis methods and object-oriented design. One of the objects chosen is SMK Istiqlal Palembang, which so far has no school profile using the website, so it is hoped that it can become a promotional media for prospective students who want to enter this school. The programming language used is PHP and the database used is MY SQL.
\end{abstract}

Keywords: Object Oriendted Analysis, Object Oriented Design, Website

\begin{abstract}
Abstrak: Profil sekolah merupakan salah satu hal yang sangat penting di dalam mempromosikan sebuah sekolah. Dengan menampilkan profil sekolah, maka pengunjung dari sebuah sekolah dapat melihat semua kegiatan belajar mengajar yang ada di dalam sebuah sekolah. Hal ini sangatlah penting mengingat profil sekolah juga merupakan media promosi yang dapat ditampilkan kepada orang lain. Di dalam pengembangan profil sekolah inilah, maka Penulis tertarik untuk membuatnya menggunakan website dengan menggunakan metode analisis dan desain berorientasi objek. Salah satu objek yang dipilih adalah SMK Istiqlal Palembang yang sejauh ini belum ada profil sekolah menggunakan website., sehingga diharapkan bisa menjadi media promosi ke calon siswa yang ingin masuk ke sekolah ini. Bahasa pemrograman yang digunakan menggunakan PHP dan database yang digunakan adalah My SQL.
\end{abstract}

Kata Kunci: Analisis Berorientasi Objek, Desaim Berorientasi Objek, Website

\section{PENDAHULUAN}

Teknologi informasi merupakan salah satu hal yang dapat menyajikan informasi yang up to date saat ini, sehingga perkembangannya sangat pesat. Dengan memanfaatkan teknologi informasi maka semua aspek kehidupan dapat didukungnya. Begitu juga dengan dunia pendidikan, baik pendidikan di tingkat dasar maupun pendidikan di tinggat tinggi.

Pemanfaatan teknologi informasi di dunia pendidikan salah satunya adalah dengan media promosi sekolah. Kita tidak bisa mengelak bahwa dunia pendidikan saat ini sangat didukung sekali oleh teknologi informasi. Jika tidak, maka sekolah kita akan sangat jauh ketinggalan. Untuk mendukung itu semua, salah satu hal yang penting adalah dengan mempromosikan sekolah di dunia internet. Jadi tidak semua orang harus datang ke sekolah kita, akan tetapi dengan hanya bermain dunia internet, maka prodil sekolah akan dapat dilihat oleh jutaan orang di dunia ini.

Salah satu objek dari penelitian ini adalah dengan mengembangkan profil sekolah di SMK Istiqlal, di mana sekolah ini belum menggunakan website sebagai media promosi sekolah. Sehingga diharapkan sebagai media untuk mempromosikan sekolahnya kepada calon siswa/siswi. Jadi calon siswa tidak perlu datang 
ke sekolah untuk melihat profil sekolah, akan tetapi bisa mengunjungi website-nya di internet.

Dalam pengembangan website, metode untuk membuat aplikasinya menggunakan metode analisis dan desain berorientasi objek. Metode analisis berorientasi objek mempunyai tahapan kerja sebagai berikut: 1) Berpedoman pada kebutuhan pemakai sistem. 2) Mengidentifikasikan skenario pemakaian atau use-case. 3) Memilih kelas-kelas dan objekobjek menggunakan kebutuhan sebagai penuntun. 4) Mengidentifikasi atribut dan operasi untuk masing-masing kelas objek. 5) Mengidentifikasi struktur dan hirarki kelas-kelas.

6) Membangun model keterhubungan kelas dan objek [1]. Sedangkan desain berorientasi objeknya juga mempunyai beberapa diagram yaitu use case diagram, activity diagram, sequence diagram, collaboration diagram dan class diagram. Masih ada beberapa diagram yang lain, yang tidak Penulis gambarkan di artikel ini.

Metode pengembangan perangkat lunak yang digunakan dalam membuat profil sekolah ini adalah Web Engineering yang terdiri dari beberapa tahapan yaitu Customer Communication, Planning, Modelling, Construction, dan Deployment [2]. Sedangkan bahasa pemrogramannya menggunakan PHP yang bersifat sebagai open source dan dapat digunakan berbagai jenis platform sistem operasi [3], sedangkan database-nya adalah MySQL. MySQL merupakan database server yang paling sering digunakan dalam pemograman PHP [4].

\section{METODOLOGI PENELTIAN}

\subsection{Metode Pengumpulan Data}

Metode pengumpulan data dalam penelitian ini adalah menggunakan berbagai macam cara. Pertama adalah dengan melakukan wawancara kepada pihak sekolah. Kedua, dengan cara mengamati kerja di sekolah. Ketiga dengan melakukan studi literatur, yaitu dengan mempelajari teori-teori yang mendukung penelitian ini.

\subsection{Metode Pengembangan Sistem}

Metode pengembangan sistem dalam penelitian ini adalah dengan menggunakan Web Engineering. Tahapan kerja dari Web Engineering adalah : 1) Customer Communication (mencari pemecahan masalah dari web), 2) Planning (merencanakan kegiatan dalam pembuatan website), 3) Modelling (metode yang digunakan yaitu analisis dan desain berorientasi objek), 4) Construction (membangun web aplikasi) dan 5) Deployment (terkirim ke end-user dan mengevaluasi secara berkala web aplikasi tersebut) [2].

\subsection{Penelitian Terdahulu}

Ada beberapa penelitian dari peneliti lain yang melatar belakangi penelitian ini. Pertama, penelitian dari Nyimas Sopiah (2012) yang juga menggunakan metode analisis dan desain berorientasi objek pada pembuatan website Jurnal Ilmiah Terpadu. Penelitiannya menghasilkan proses pengiriman artikel sampai dengan artikel tersebut terbit [5]. 
Penelitian kedua yaitu penelitian dari Eva Khudzaeva (2014). Penelitiannya juga menggunakan metode berorientasi objek yang menghasilkan sistem arsip akreditasi di UIN Hidayatullah Jakarta [6].

\section{HASIL DAN PEMBAHASAN}

Metode analisis dan desain berorientasi objek dapat diuraikan sebagai berikut:

\subsection{Analisis Berorientasi Objek}

\subsubsection{Berpedoman pada Kebutuhan Pemakai \\ Sistem}

Tahap pertama dari analisis berorientasi objek adalah berpedoman pada kebutuhan pemakai sistem. Tahap ini merupakan tahap di mana menguraikan tentang apa yang dibutuhkan oleh sistem yang akan dibangun. Berikut gambar dari sistem yang akan dibangun dalam alur kerja (workflow).

Pada gambar 1 terdapat tiga peran yang terlibat yaitu siswa, admin dan guru. Setiap peran mempunyai tugasnya masing-masing. Siswa bisa melihat pengumuman, berita dan dapat mengunduh materi mata pelajaran. Admin dapat menambahkan dan mengubah data-data tadi. Selain itu admin juga bisa mengolah data siswa, guru dan kelas. Sedangkan guru selain dapat mengakses data yang dapat dilihat oleh siswa, guru juga bisa mengakses data guru serta dapat mengubah datanya sendiri.

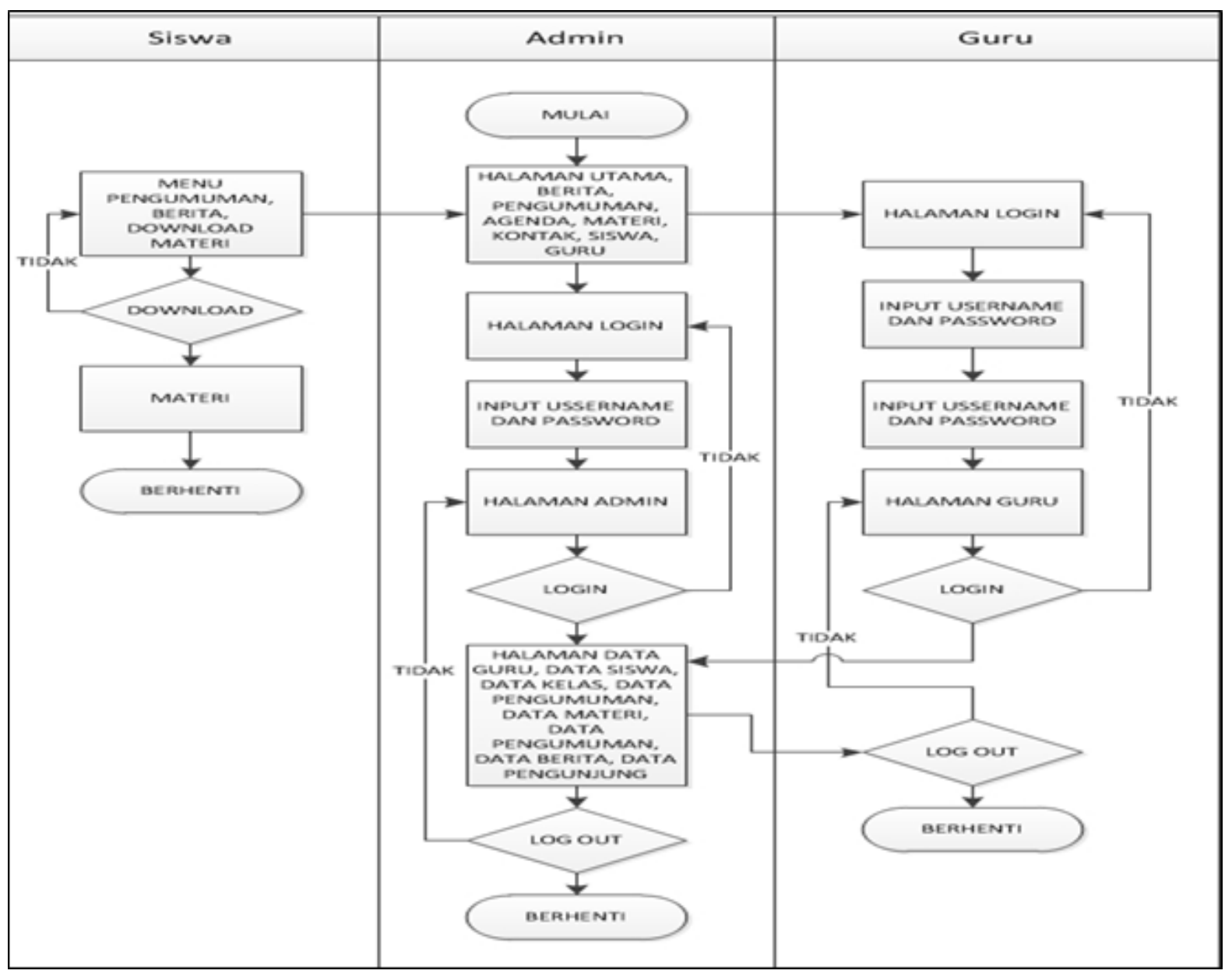

Gambar 1. Alur Kerja Sistem 


\subsubsection{Mengidentifikasi Skenario Pemakaian atau Use Case}

Setelah membuat alur kerja, tahap berikutnya adalah dengan membuat skenario. Skenario yang dibuat terdiri dari tiga belas skenario, yaitu kelola data admin, ogin menu admin, tambah data admin, pengumuman, berita, agenda kegiatan, galeri foto, pengunjung, data siswa, data guru, akses menu guru, login menu guru, dan upload materi.

\subsubsection{Memilih Kelas-Kelas dan Objek}

Tahap ini adalah tahap dimana dapat memilih kelas dan objek dari skenario yang telah dibuat. Terdapat tujuh belas objek yaitu admin, pengumuman, materi, album, agenda, galeri, pengunjung, siswa, guru, file, inbox, kategori, kelas, komentar, log aktifitas dan tulisan., dan mata pelajaran. Sedangkan terdapat enam belas kelas yaitu admin, pengumuman, materi, album, agenda, galeri, pengunjung, siswa, guru, file, inbox, kategori, kelas, komentar, log aktifitas dan tulisan.

\subsubsection{Mengidentifikasi Atribut dan Operasi untuk Masing-masing Kelas Objek}

Setelah ditentukan kelas dari tahap sebelumnya, maka kelas-kelas tersebut diidentifikasikan atribut dan operasinya. Kelas pertama yaitu kelas Admin mempunyai atribut (no_admin, ussername, password, judul, tulisan, tanggal, nama_penerbit, pengumuman, berita_acara, agenda_kegiatan, galeri_foto, pengunjung) dan operasi (browser, edit, simpan, kirim, tampil).

Kelas kedua yaitu Pengumuman mempunyai atribut Judul, Tulisan, Tanggal, dan
Nama_penerbit). Operasinya yaitu edit, simpan dan delete. Kelas ketiga yaitu kelas Berita_Acara. Kelas ini mempunyai atribut Judul, Tulisan, Tanggal, dan Nama_penerbit. Operasinya yaitu edit, simpan dan delete.

Kelas berikutnya yaitu kelas keempat adalah kelas Agenda_Kegiatan. Kelas ini mempunyai atribut Judul, Tulisan, Tanggal, dan Nama_penerbit. Operasinya yaitu edit, simpan dan delete.

Kelas kelima yaitu kelas Galeri_foto yang mempunyai atribut album, nama foto, tanggal, dan nama_penerbit Operasinya yaitu edit, simpan dan delete. Kelas keenam yaitu kelas Pengunjung yang mempunyai atribut Nama_pengunjung, Email_pengunjung, Tanggal Dan pesan. Operasinya yaitu edit, simpan dan delete.

Kelas ketujuh yaitu kelas Siswa. Kelas ini mempunyai atribut nama_siswa, alamat, id, kelas, kontak nomor dan foto. Operasi pada kelas ini yaitu browser dan download_materi. Kelas kedelapan yaitu kelas Guru. Kelas ini mempunyai atribut NIP, ussername, password, nama, alamat, kontak nomor, materi_pelajaran, tulisan, tanggal, nama_penerbit dan kelas. sedangkan operasi pada kelas ini adalah browser, edit, simpan, kirim dan tampil.

Kelas terakhir atau kelas kesembilan yaitu kelas Upload_materi. Kelas ini mempunyai atribut judul, materi, tanggal dan nama_penerbit. Operasinya yaitu edit, simpan, delete, dan kirim.

\subsubsection{Mengidentifikasi Struktur dan Hirarki Kelas-kelas \\ Struktur kelas terdiri dari tiga, yaitu kelas main, kelas tampilan sistem dan pendefinisian}


skenario use case. Untuk kelas main yaitu website sekolah SMK Istiqlal. Kelas tampilan sistem terdiri dari kelas login admin, menu admin, login guru, menu guru, pengumuman, berita acara, agenda kegiatan, galeri foto, siswa, guru dan upload materi. Sedangkan kelas pendefinisian skenario use case yaitu kelas admin, pengumuman, materi, album, agenda, galeri, pengunjung, siswa, guru, file, inbox, kategori, kelas, komentar, log aktifitas dan tulisan.

Hirarki kelas merupakan uraian dari struktur kelas, di mana kelas main berada paling atas, kemudian di bawahnya kelas yang menangani tampilan sistem dan urutan paling bawah lagi adalah kelas pendfinisian skenario use case.

\subsubsection{Membangun Model Keterhubungan Kelas dan Objek}

Tahap berikutnya adalah dengan menghubungkan relasi antar kelas. Berikut relasi antar kelas dari kelas-kelas yang telah diuraikan sebelumnya. Kelas tulisan berelasi ada di dalam kelas agenda. Kelas album berelasi ada di dalam kelas galeri. Kelas materi berelasi ada di dalam kelas kelas. Kelas admin berelasi ada di dalam kelas agenda. Kelas materi berelasi ada di dalam kelas guru. Kelas materi berelasi ada di dalam kelas admin. Kelas guru berelasi ada di dalam kelas admin. Kelas pengunjung berelasi ada di dalam kelas log aktifitas. Kelas guru berelasi ada di dalam kelas log aktifitas. Kelas admin berelasi ada di dalam kelas log aktifitas. Kelas inbox berelasi ada di dalam kelas pengunjung. Kelas kategori berelasi ada di dalam kelas tulisan.
Kelas admin berelasi ada di dalam kelas inbox. Kelas admin berelasi ada di dalam kelas galeri. Kelas admin berelasi ada di dalam kelas tulisan. Kelas guru berelasi ada di dalam kelas tulisan. Kelas pengumuman berelasi ada di dalam kelas tulisan. Kelas pengumuman berelasi ada di dalam kelas admin. Kelas siswa berelasi ada di dalam kelas kelas.

\subsection{Desain Berorientasi Objek}

Di dalam merancang aplikasi ini ada beberapa diagram yang sudah dibuat untuk mendukung proses perancangan berorientasi objek. Diagramnya akan diuraikan berikut ini.

\subsubsection{Use Case Diagram}

Use case diagram merupakan diagram yang menghubungkan antara aktor dan use case. Ada 4 aktor yaitu admin, guru, siswa dan pengunjung. Sedangkan use case nya ada 13 use case. Use case diagram terdapat pada gambar 2.

\subsubsection{Activity Diagram}

Diagram berikutnya adalah activity diagram. Activity diagram merupakan diagram yang menguraikan urutan kegiatan di dalam aplikasi. Activity diagram yang telah dibuat dapat dilihat pada gambar 3 


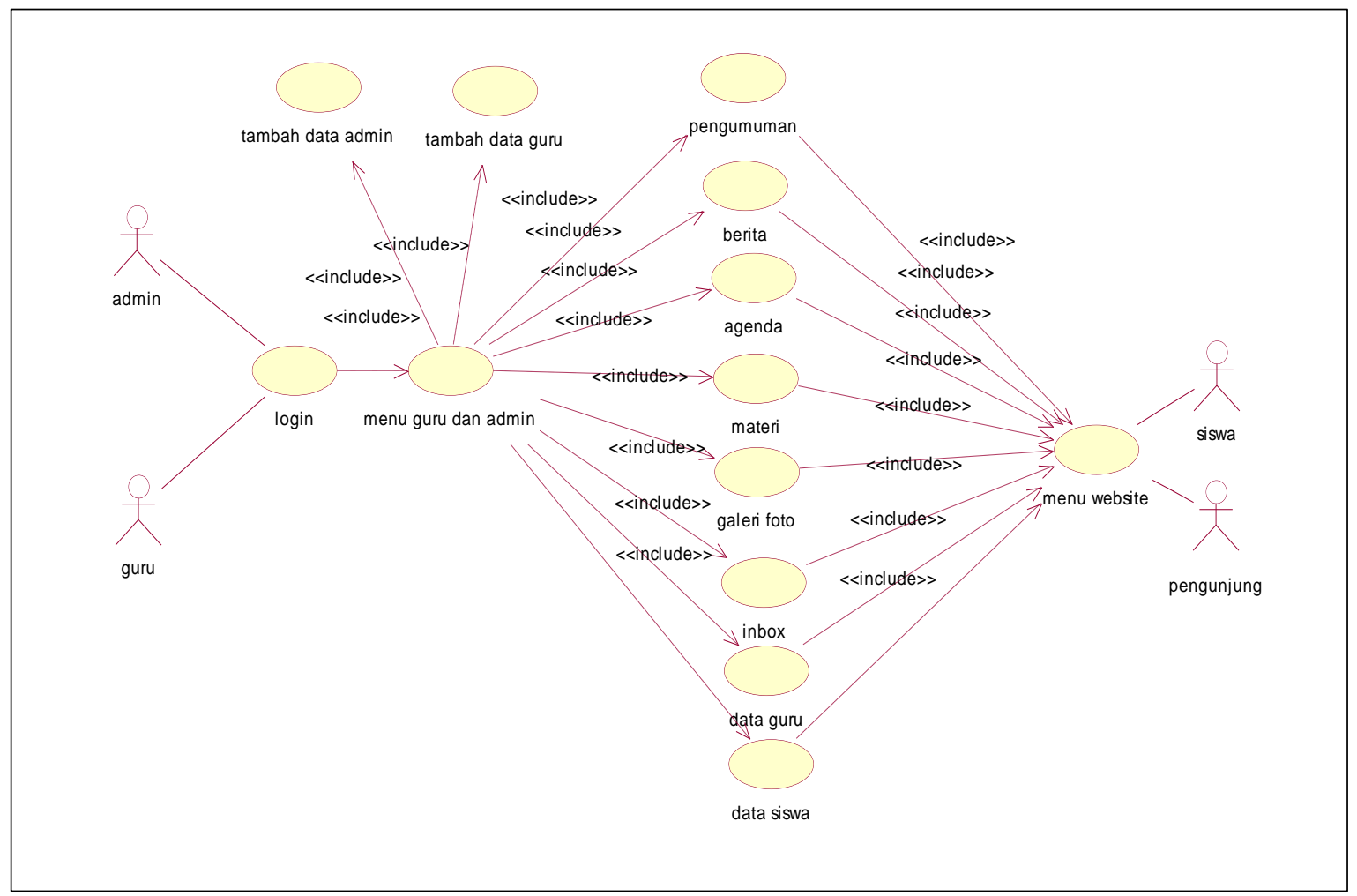

Gambar 2. Use Case Diagram

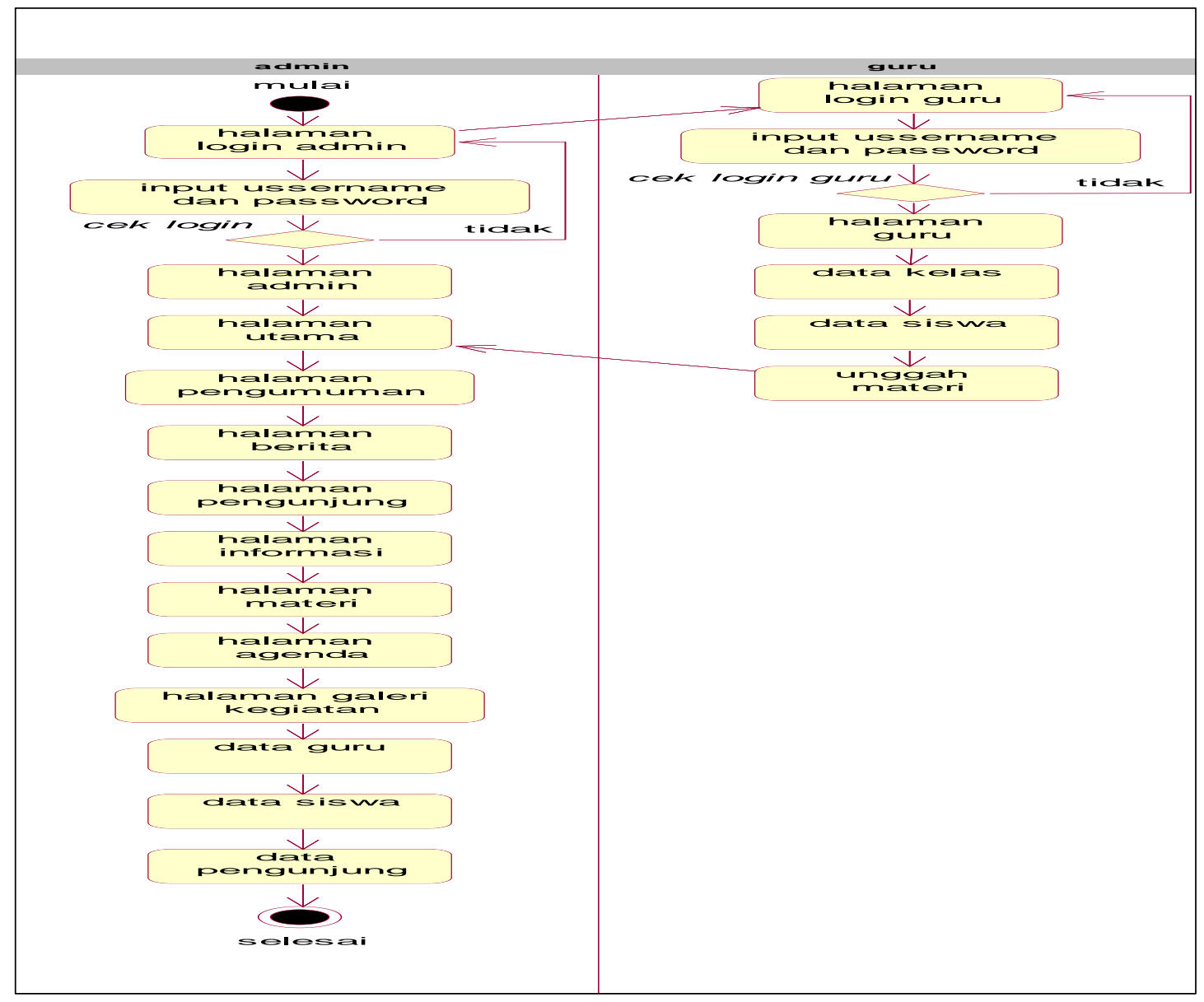

Gambar 3. Activity Diagram 


\subsubsection{Sequence Diagram}

Diagram berikutnya merupakan diagram yang menguraikan hubungan antar objek. Objek dari diagram ini diperoleh dari tahap analisis berorientasi objek. sequence diagram dapat dilihat pada gambar 4.

\subsubsection{Collaboration Diagram}

Collaboration Diagram merupakan diagram yang menguraikan kolaborasi antar objek. Objeknya juga berasal dari tahap analisis berorientasi objek. Collaboration diagram dapat dilihat pada gambar 5 .

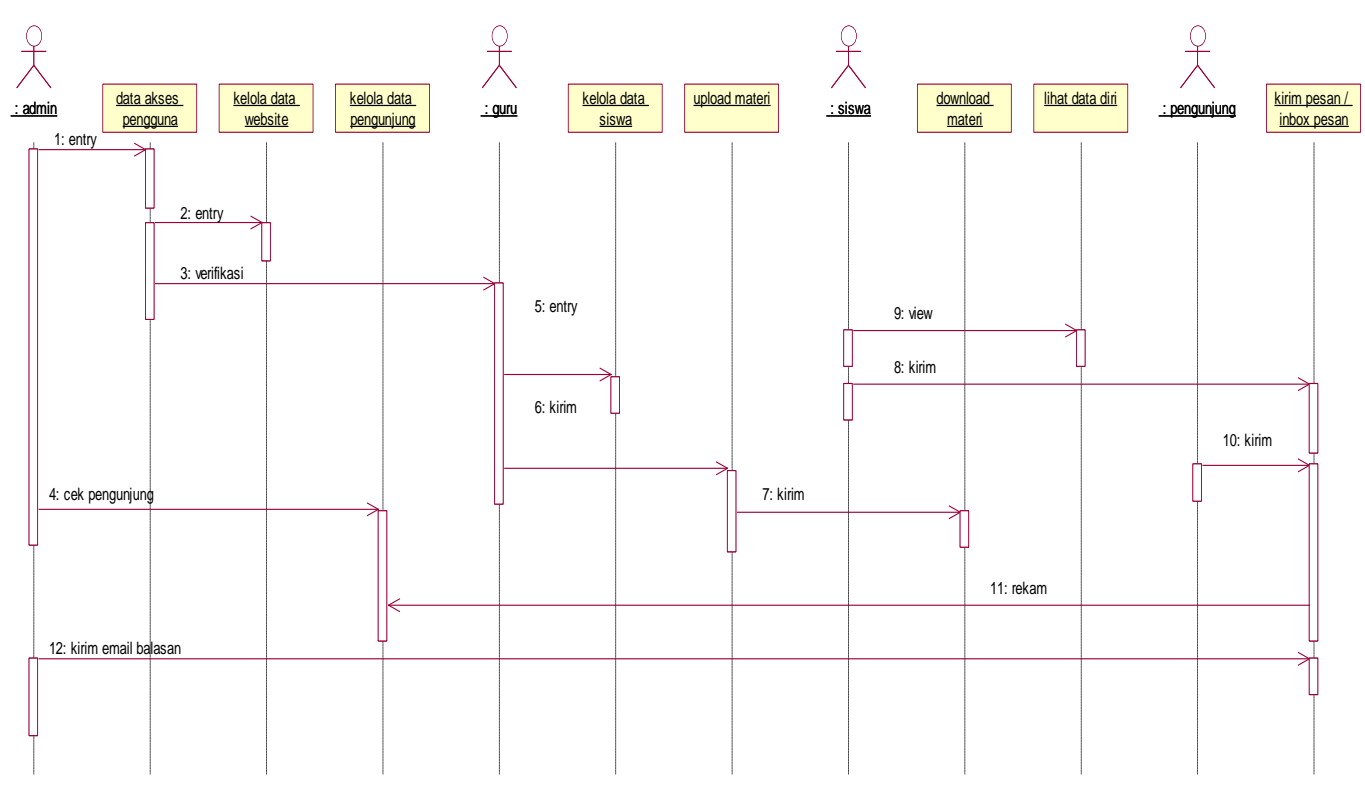

Gambar 4. Sequence Diagram

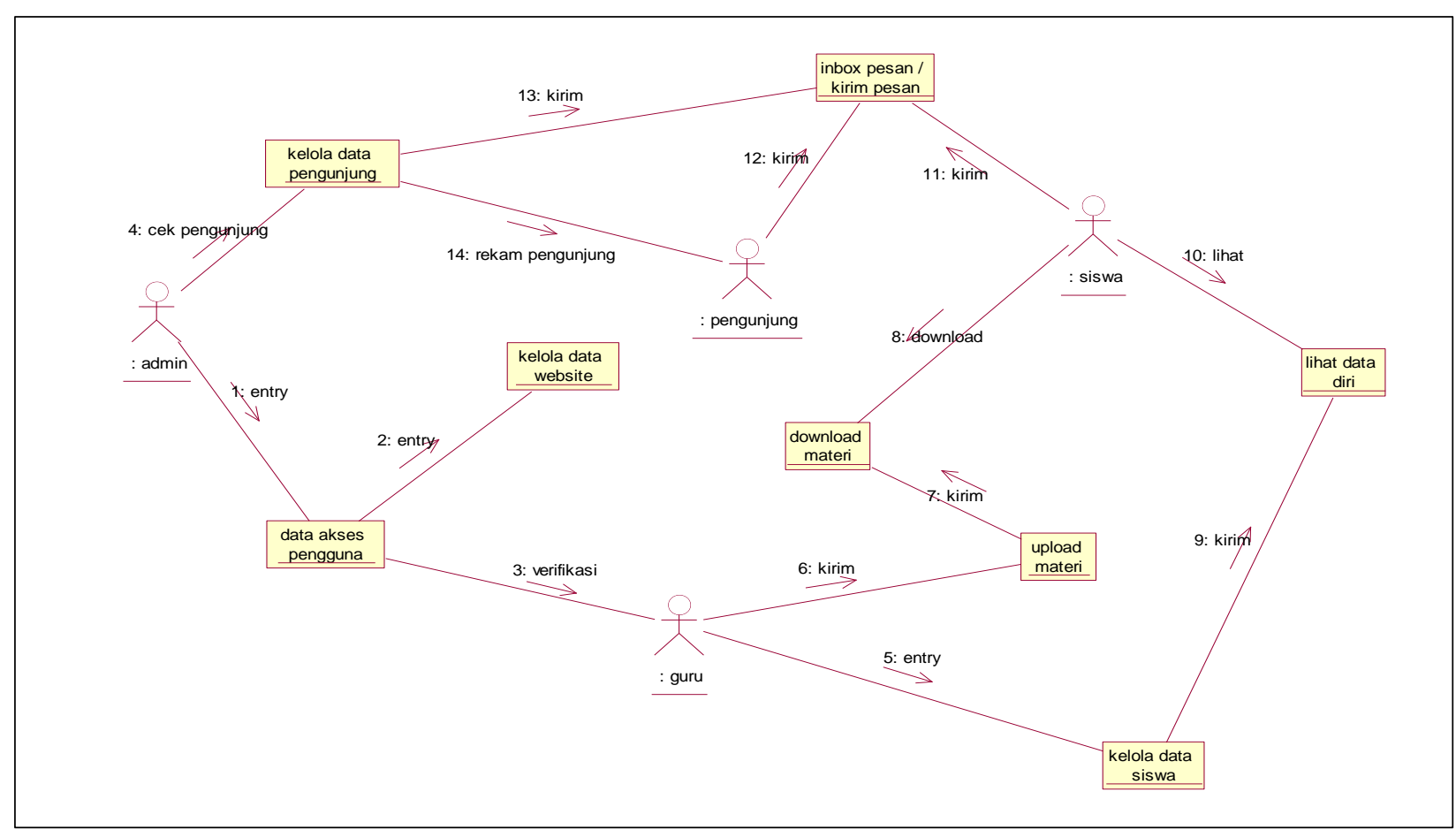

Gambar 5. Collaboration Diagram 


\subsubsection{Class Diagram}

Class diagram merupakan diagram yang menghubungkan relasi antar kelas. Kelas dan relasi sebelumnya telah dibuat pada tahap analisis berorientasi objek. Berikut class diagram nya.

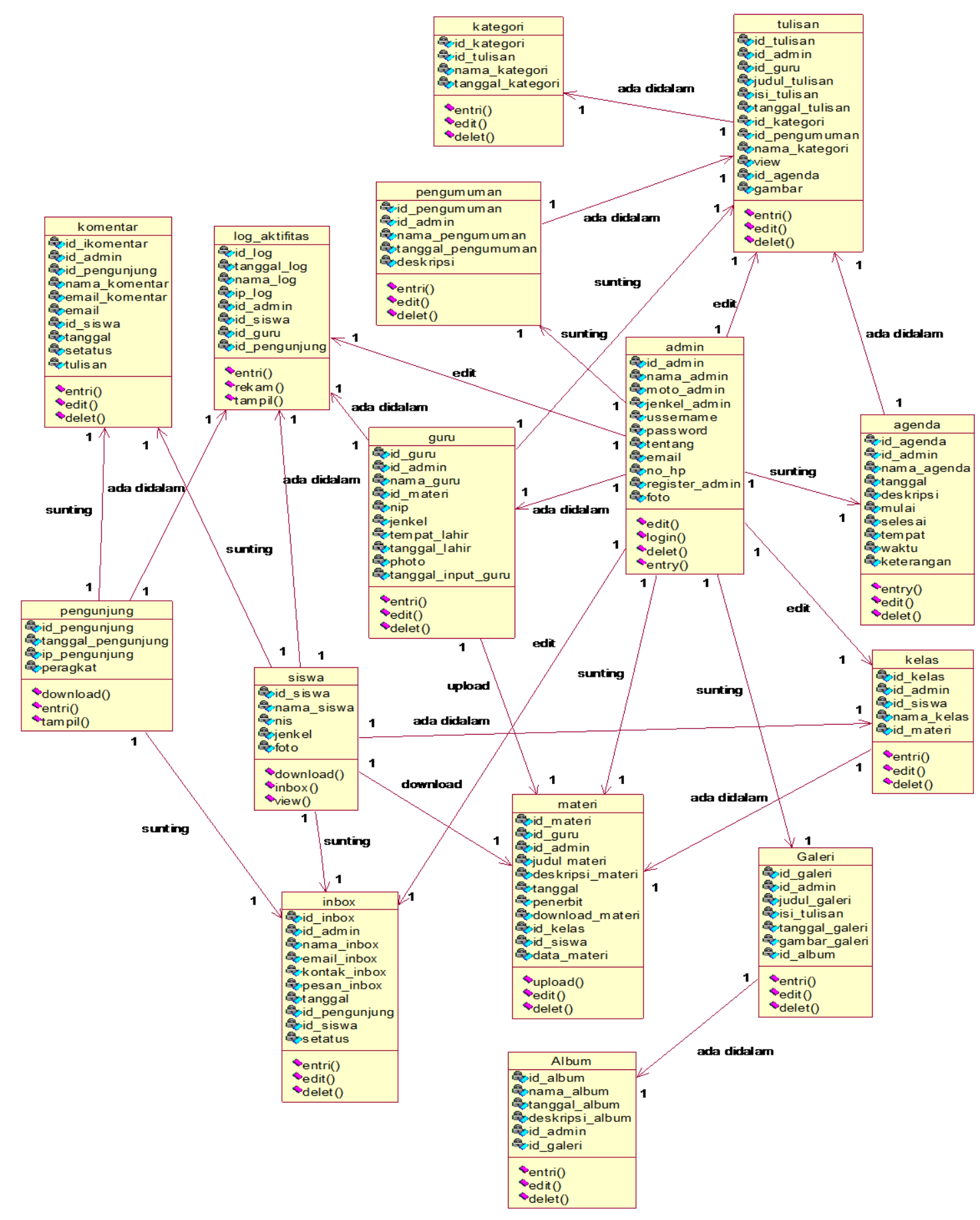

Gambar 6. Class Diagram 


\subsection{Hasil yang Dicapai}

Setelah dilakukan analisis dan desain, maka aplikasi telah dibuat. Aplikasi yang telah dibuat menampilkan profil sekolah SMK Istiqlal. Ada beberapa tampilan di menu yang bisa diakses oleh pengunjung yang dapat diuraikan sebagai berikut:

\subsubsection{Tampilan Beranda}

Tampilan beranda merupakan tampilan yang menampilkan halaman depan dari website. Tampilan ini akan diakses oleh pengunjung website.

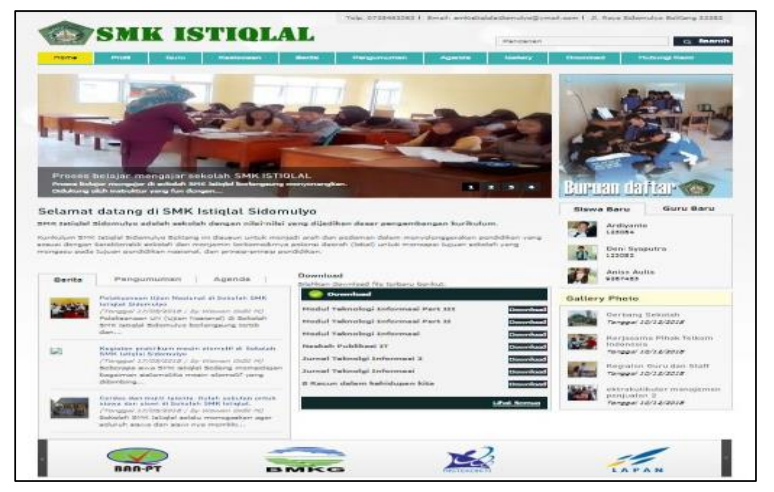

Gambar 7. Tampilan Beranda

\subsubsection{Tampilan Sambutan}

Tampilan sambutan merupakan tampilan yang memuat kata sambutan dari Kapala Sekolah SMK Istiqlal. Tampilannya dapat dilihat pada gambar 8 berikut ini.

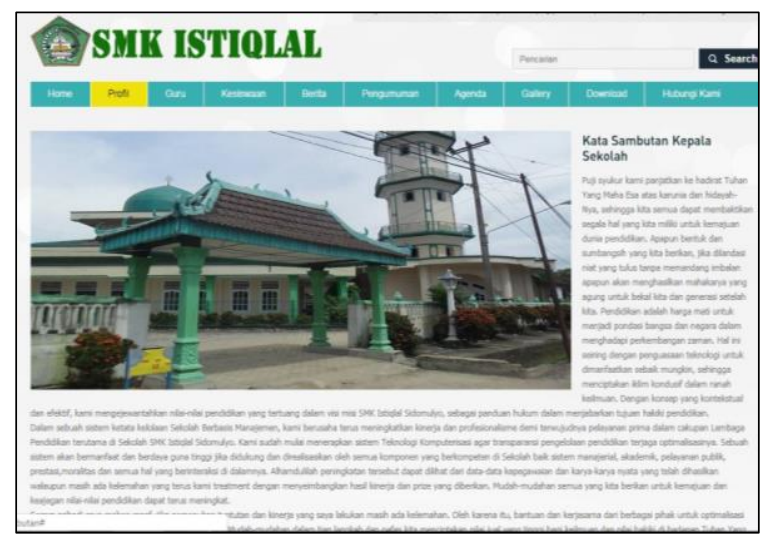

Gambar 8. Tampilan Sambutan

\subsubsection{Tampilan Data Guru}

Tampilan data guru merupakan menu yang menyajikan informasi tentang profil dari guru SMK Istiqlal, bisa dilihat pada gambar 9.

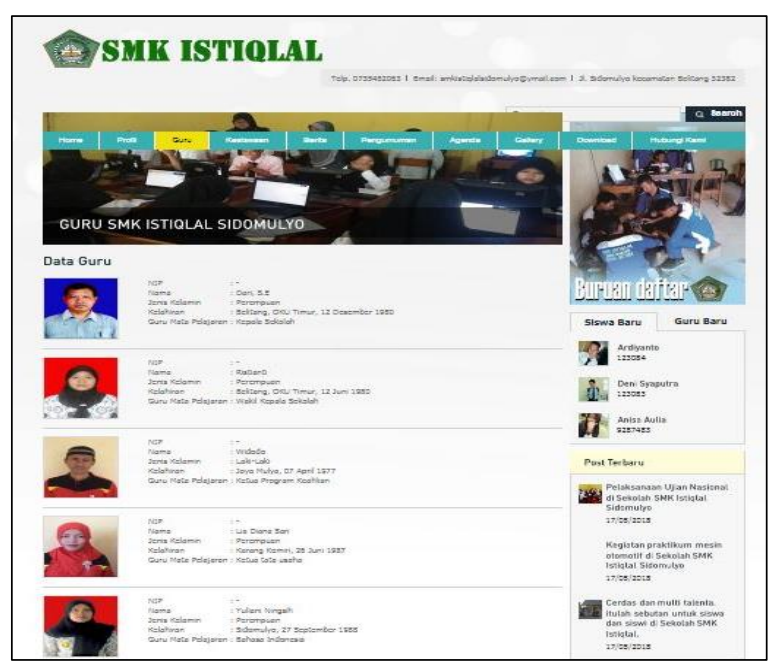

Gambar 9. Tampilan Data Guru

\subsubsection{Tampilan Data Siswa}

Tampilan data siswa memuat tentang profil siswa SMK Iqtiqlal. Jadi seswa siswa yang berada di sekolah ini dapat ditampilkan pada gambar 10.

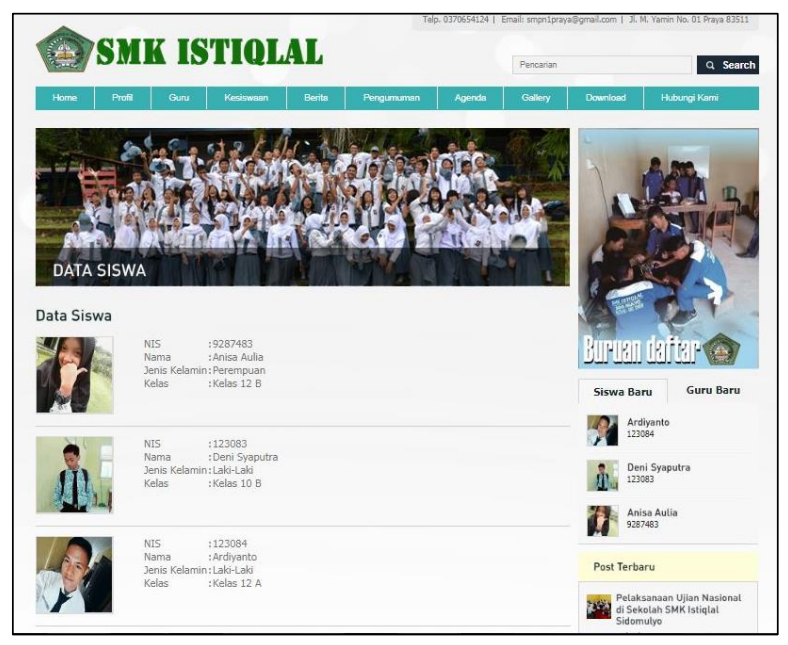

Gambar 9. Tampilan Data Siswa

\subsubsection{Tampilan Download Materi}

Download materi merupakan menu di mana siswa dapat men-downlod materi pelajaran yang mereka ikuti. 


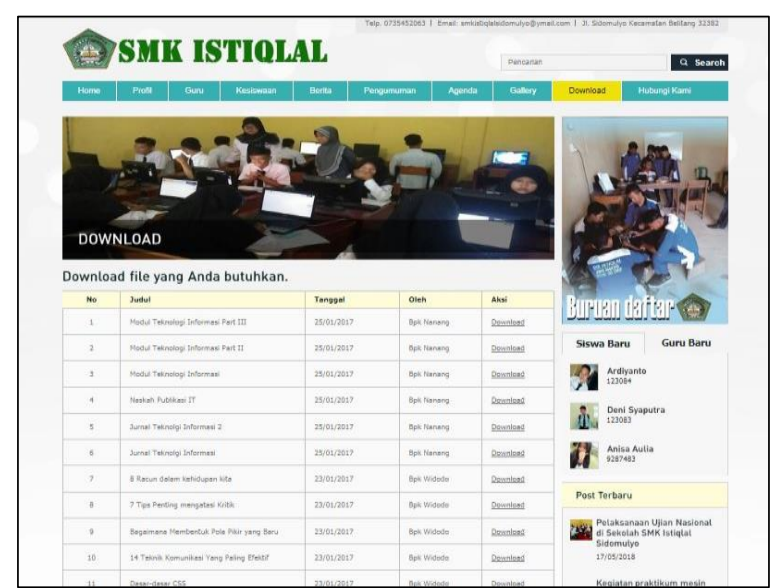

Gambar 10. Tampilan Data Siswa

\subsubsection{Tampilan Galeri}

Tampilan galeri memuat informasi tentang foto-foto dari kegiatan proses belajar mengajar dan kegiatan siswa di SMK Istiqlal.

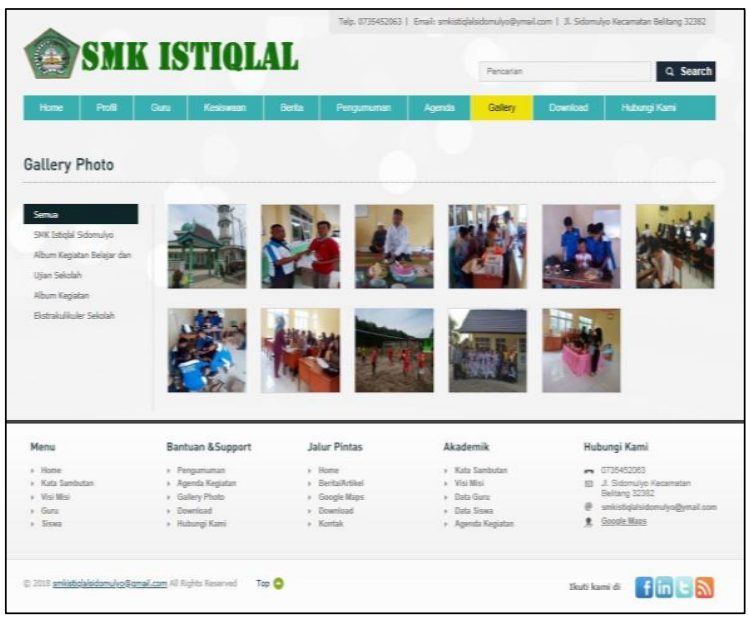

Gambar 11. Tampilan Galeri

\subsubsection{Tampilan Hubungi Kami}

Tampilan hubungi kami memuat infomasi tentang kontak sekolah yang dapat dihubungi oleh pengunjung.



Gambar 12. Tampilan Hubungi Kami

Setelah menampilkan informasi dari profil SMK Iqtiqlal. Pengelola website dalam hal ini Admin dapat mengubah data-data tersebut dengan loginnya, di mana Admin dapat memasukkan user id dan password. Data yang bisa diubah yaitu data berita, pengguna, agenda, pengumuman, download, gallery, data guru, dan data siswa. Gambar 13 menunjukkan contoh menu yang bisa di-update oleh Admin.

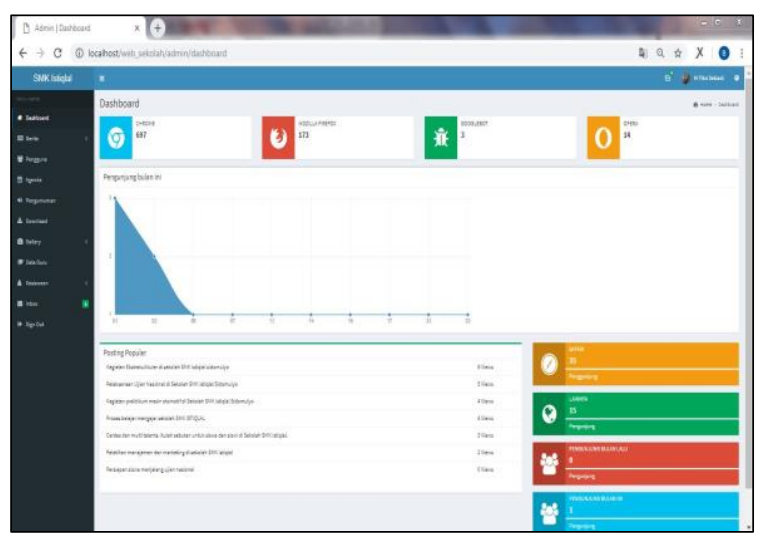

Gambar 13. Menu Admin

\section{SIMPULAN}

Berdasarkan dari hasil penelitian yang telah dilakukan pada SMK Istiqlal, maka dapat disimpulkan, pertama telah dihasilkan aplikasi profil sekolah SMK Istiqlal berbasis website. Kedua, website profil tersebut diharapkan dapat membantu pihak sekolah di dalam mempomosikan semua kegiatan sekolah. 


\section{DAFTAR RUJUKAN}

[1] Haryanto, Bambang., Rekayasa Sistem Berorientasi Objek. Informatika, Bandung. 2004.

[2] Pressman, Roger S. Software Engineering: A Practitioner's Approach., McGraw-Hill, New York. 2010.

[3] Nugroho, Bunafit., Dasar Pemograman Web PHP-MySQL dengan Dreamweaver. Gava Media, Yogyakarta. 2013

[4] Komang, I Setia Buana., Jago Pemrograman PHP. Dunia Komputer, Jakarta. 2014.

[5] Sopiah, Nyimas., "Penggunaan Metode Analisis dan Rancangan Berorientasi Objek pada Web Jurnal Ilmiah Terpadu", Seminar Nasional Informatika (SEMNASIF) Vol.1 No.4 Tahun 2012. Universitas UPN Yogyakarta, Yogyakarta. 2012

[6] Khudzaeva, Eva., "Rancang Bangun Sistem Arsip Akreditasi (Studi Kasus: Fakultas dan Teknologi UIN Syarif Hidayatullah Jakarta)", Jurnal Sistem Informasi Volume 7 Nomor 2, Oktober 2014. 